\title{
Superintendents and Legislators: Actors in the Educational Policy Process on the Kansas Stage
}

\author{
Nathan Reed, Winfield District Schools, nathan_reed@usd465.com, ORCID: 0000-0002-0954-1968 \\ Bilal Obeidat, Al Ain University, bilal.obeidat@aau.ac.ae, ORCID: 0000-0002-1527-3349
}

\begin{abstract}
The purpose of this study was to understand if the advocacy efforts of superintendents had any effect during a recent policy creation. The study sought also to understand the influences state legislators consider in Kansas in determining the decisions they make when voting. Participants of this study included seven school superintendents and eight legislators, all-active in their roles during the 2015 Legislative session. In all, fifteen individual interviews were conducted, the representation of the legislators and superintendents cover a wide-range of geographical, demographic, and political affiliation. The findings and conclusions were analyzed using the theoretical framework from Murray Edelman, using the art of conducting a drama as a metaphor for policy development and action, and provide implications for advancing the understanding of the theory and practice of advocating efforts with legislators.
\end{abstract}

Keywords: Superintendents; Legislators; Educational policy, Kansas

Received: $11.11 .2020 \quad$ Accepted: $10.12 .2020 \quad$ Published: 05.01.2021

\section{INTRODUCTION}

U.S. stakeholders from many perspectives are discouraged with state and federal political systems and legislative responses to modern contemporary issues (Heise \& Nechyba, 1999). The state and local political landscape are especially volatile regarding domestic concerns such as equality, racism, and education (Baker, 2005). Concerns turn into issues that must be decided. When decisions are necessary, debates and controversies ensue.

In the middle of the debates about school reform are legislators and superintendents who often find themselves in disagreement about how to properly govern schools and how to provide for them (Baker, 2005). Concerns turn into issues that must be decided. When decisions are necessary, debates and controversies ensue.

The history of education reform is one of doing things to other people supposedly for their own good (Levin, 2000). People have become increasingly detached from public schools and have grown unsupportive. At one time the schools provided a shared context of receiving and understanding messages about political communication (Bennett \& Iyengar, 2008). Politics and symbolism create an environment that clouds the public's ability to distinguish whether a reform idea is a tool for change or for upheaval (Brown, 2007). In the middle of the debates about school reform are legislators and superintendents who often find themselves in disagreement about how to properly govern schools and how to provide for them (Baker, 2005).

Thus, one of the most fiercely debated issues is funding K-12 public education. According to Leachman and Mai (2014), every state funds K-12 public schools relying on state generated funds along with other revenue sources such as local and federal funds. The funding comes through formulas that allocate the state aid based on the individual needs of each district. Consequently, if nearly all education policies involve funding, legislators and superintendents frequently debate over funding.

The state of Kansas is no exception, as it has a passionate history with school finance debate and litigation (Rose, 2015). In 2015, the state's public school funding formula of over 20 years enacted in 1992 was removed by legislative action and replaced with another, temporary funding mechanism (Shorman, 2015). This study utilized Kansas and the temporary system of block grants per Senate Bill 7 (Rose, 2015) as the context for examining policy creation as a form of theater and the parts actors played during the act of political spectacle (Edelman, 1988). 


\section{Research Problem}

The more school superintendents actively engage with legislators while building rapport, the better the chance they have to assist in creating policy at the state level. Superintendents are advised by pre-service instruction and mentor superintendents to spend time and energy communicating with legislators and testifying in an attempt to advocate for their respective districts and the students they serve.

However, in some cases it is possible legislators have already made decisions before asking superintendents for their input. The hinge point of the phenomenon is whether and how much direct influence superintendents have with legislators during the creation of educational policy. If decisions are pre-made, superintendent input is likely to be symbolic and they play figurative roles that are largely ceremonious. In pursuit of clarity, searching for actions occurring behind the curtain of political theater to see what it is important. If the theater of policy-making happens in front of the curtain, as well as the behind the curtain, it is essential to know who the players in the drama are and how the process works.

\section{Context of the Study}

This study took place in the state of Kansas, which has been in the limelight recently because of political action and the media's analysis of what drove policymakers to enact new or alternative school funding policies. In the last thirty years, Kansas has had several school funding debates and Supreme Court cases. This brief review of recent years will shed light on events leading up to the Gannon v. the State of Kansas lawsuit and subsequent enactment of Senate Bill 7, which were the focus of this study and are detailed in the following section.

In this study, we examined the process of state educational policymaking through the perspectives of Kansas superintendents and legislators. Superintendent input to assist in decision-making is communicated to legislators and legislative committees through testimony to committees as well as phone calls, emails, social media postings, and third party advocacy (Kansas Legislative Research Department, 2015). The rhetoric used during this time and the reality of the policy created assisted in examining the process as a drama with actors who play roles designated by their positions. Specifically, we analyzed the political staging and symbolism that ensued during the 2015 legislative session.

This study explored the relationship between rhetoric during policy creation and the results enacted for educational finance reform in the state of Kansas; what actually happened versus what was said? Who had the opportunity to participate and who did not?

\section{Research Questions}

1. How do state legislators and district superintendents describe their relationships regarding educational policy creation?

2. How do state legislators and district superintendents describe the policy process that shaped the conceptualization and eventual adoption of the K-12 block grant funding formula?

\section{LITERATURE REVIEW}

\section{Politics and Education}

The advocacy efforts of superintendents in the political arena are now an important part of their roles, and in the current political climate are more important than ever (Maldonado, 2007). However, this ascertainment was not always acknowledged. It was once believed that school officials should operate "apolitically," or without politics. Educators were not to descend into the world of politicians, but to remain professional (M. W. Kirst \& Wirt, 1989). Nonetheless, it is now well accepted that education and politics intersect and the tasks of superintendents are highly political in nature due to the demands of the position. When the topics of education and politics intertwine, there are consequences and reactions.

\section{Spillover Effects}

Unintended outcomes are those policy consequences that diverge from the goals sought by the established change to the institution, which may detract from the reformer's goals (Cortell \& Peterson, 2001). As Angelucci and Di Maro (2016) went on to explain, interventions have a specific target population. The direct effect of the program is intended for this group. However, a non-target group may be indirectly affected by the intervention. In many cases, the social and economic interaction of the non-target group is 
altered unintentionally. For example, children who receive free textbooks and computers in an impoverished school district share them with the "untreated" population of students raising student engagement with both groups of students, so the students who did not receive the free instructional tools still benefitted (Angelucci \& Di Maro, 2016).

Another way spillover works is at the state level. For example, the spending of neighboring states may influence some states. Consequently, states' policy changes can spillover or effect the other states around them (Baicker, 2005). A main reason for neighboring states to be concerned with each other and how money is raised and spent is the competition for taxpayers. Welfare systems and tax structure migration are noted as the top two motivators for migration. This is again, another consequence or spillover effect of policy (Baicker, 2005).

\section{Public School Funding Equity and Adequacy}

Policies determine how resources are generated, allocated, and used to produce and educate the public of the values of the majority (Baker et al., 2010). Policymakers often ask to what degree these resources affect the learning of students. Does more money equate to better results is a common question (Cooper et al., 2004). Moreover, the student population has increased alongside the rate of spending (Baker \& Corcoran, 2012; Cooper et al., 2004). Notwithstanding, one cannot conclude that all policies created ensure that funds are spent effectively (Cooper et al., 2004). What is important to know is of whom the policymakers are asking these questions. This study explored that very notion.

\section{The Superintendent's Role as Political Strategist}

The job of a school superintendent is highly complex and includes much more than managing the day-today activities of a school district. A superintendent is expected to negotiate with teachers, students, parents, unions, community bureaucracies, businesses, governing bodies, and politicians. To negotiate and manage so many fronts, a superintendent has to understand pressures, stresses, and interests of others with whom they work with. They rarely control their own agenda (Fuller et al., 2003).

\section{Political Advocacy of Superintendents}

The superintendent must be adept at working with local and state officials, district personnel, and the community as a whole (Wimpelberg, 1997). It is the responsibility of school leaders and politicians in a democracy to develop personal and professional relationships. Consequently, a good rapport allows those on different sides of an issue to engage in meaningful dialogue to create discourse based on mutual trust and respect. The existence of such a relationship allows opposing views to listen to one another and compromise when necessary in order to achieve desired goals (Gonzalez \& Carney, 2014).

With so many other influences on legislators, it is hard to determine the extent in which they internalize what local school superintendents communicate to them. There is little to no empirical evidence that supports superintendents' efforts to influence funding policy (Johnson, 1996).

When the standards-based approach of No Child Left Behind reform took hold nationwide, power continued to shift from local school boards to state and federal policymakers (Reback, Rockoff, \& Schwartz, 2011). This shift started as far back as the passage of the National Defense Education Act in 1958 in response to the Cold War and Sputnik. The premise of improving student achievement through classroom standards and more importantly high stakes testing forced superintendents to be more political on a state and federal level. The diminishing local control frustrated many school boards and superintendents. These were initiatives that were dictated to address the needs of the students in their district that they had knowledge and expertise on (Conley, 2003). Systematic state accountability in education reform that controls state content standards holds local districts and schools directly responsible through high stakes testing. State policymakers have a greater impact on local school practice by narrowing local programming choices and expected outcomes. There has been very little attention brought directly to this relationship and the role state policies play through research (Prestine, 2005).

\section{Superintendents as Actors on the Political Stage}

Superintendents are the political advocates for their district (Hoyle, Bjork, Collier, \& Glass, 2004; Johnson, 1996). Therefore, district leaders need to be politically active and effective at working with various political groups and governmental bodies (Hughes \& Hooper, 2000; Lunenburg \& Ornstein, 2004). The political skill of the school superintendent can be crucial to student success (Maldonado, 2007). Furthermore, Bolman 
and Deal (2003) view organizations through a political frame. They asserted a school leader's most important role is to be persuasive and influential as advocates for their districts in a political field that has many players representing competing interests.

Notwithstanding, some school superintendents often have an aversion to politics. Johnson (1996) suggested those who have an aversion to politics do not fully understand the demands of the position. School superintendents are expected to be champions for their districts and participatory democracy compels them to make their voice heard at the state level politically (Maldonado, 2007).

\section{Influences on Policymakers Regarding Education Policy Decisions}

\section{Internal Influences}

Strategically placed groups and individuals are internal to the legislators and have access to opportunities that may influence policymakers. They are considered internal because they have daily access to legislators during the legislative sessions. Among this list are fellow legislators, legislative staff, and state organizations (Bonewald, 2013). For legislators, it has been found when a decision is measured and weighed, that one approach is the policy be viable politically and not threaten current coalitions (Campbell, 2002). In fact, Oh and Rich (1996) postulated that decision makers with higher positions tend to consult in-house research because it is easily accessible as well as the belief that the information is more in-line with the interests of the organization.

\section{External Influences}

External influences seek time and attention from policymakers as well. These groups attempt to influence legislators and ultimately the policies they develop. These influences are considered external because they are not part of the legislators' inner circle of staff and other legislators. These influences include special interest groups, professional organizations, big business, and the media. In this mix of external players is the public school superintendent who is advocating for his or her district. Lobbying strategies at the state level mirror that of the national level. Partisanship is risky and in a two-party system it is most effective if lobbyists support both parties (Kirst \& Wirt, 2009). However, individual lawmakers tend to not want longterm obligations to any one group (Spring, 1998).

\section{METHODS}

\section{Research Participants}

Study participants consisted of Kansas' legislators and superintendents. To be eligible, the participants needed to have played a role in advocating and testifying during the debates of SB 7 of legislative session 2015. Eight legislators and seven superintendents were interviewed. We sought out legislators who sat on the committees of Ways and Means, Education, and Appropriations during the same session as well as other superintendents advocating for public education funding at the hearings held during the 2015 legislative session. It took several rounds of communication to get some legislators to commit to participating. We emailed my list twice and called twice, either leaving messages or talking to the potential participants on the phone. We identified prospective participants through purposeful sampling. Purposeful sampling means researchers intentionally select individuals and sites that meet a certain criteria to inform on a central phenomenon (Creswell, 2012). Purposeful sampling set the criteria for participants that informed the focus of the study. Two individuals at the Kansas Association of School Boards (KASB) agreed to aid me with the purposeful sampling. KASB has a network of superintendents that attend training for legislative advocacy. Another useful agency was the Kansas State Department of Education (KSDE) whose employees directed me to potential superintendent and state legislator participants. Still another resource was the council of superintendents from area service centers and the Kansas School Superintendents Association (KSSA). These organizations were able to offer guidance in selection of participants as was the transcripts from the proceedings of the committees assigned to host hearings on SB 7. We learned that we did not need a larger number of participants to collect rich and rigorous data (Tracy, 2010). We had as many participants as possible from the legislators and superintendents that met the criteria for participation during the recruiting timeframe. We identified a possible 23 participants and 15 agreed to participate in the study. 


\section{Individual Interviews}

We employed a semi-structured interview protocol. In this type of interview, flexibility of the questions is important. The largest part of the interview is guided by a list of questions or issues to be explored, to the emerging viewpoint of the respondent, and to the new ideas of the topic (Merriam, 2014). There were interview protocols of questions that mirrored each other, some questions were specifically for superintendents while another list for legislators. Each interview was 45-60 minutes in length

\section{Data Analysis}

Each interview was transcribed immediately following the interview session. During transcription of my recorded interviews, we executed the verbatim practice, which is to type every word, noise, pause, or reaction we can (Merriam, 2014).

We used the constant comparative method whereby data was compared to each other to find similarities and differences (Lapan et al., 2012). Codes were scrutinized as new data was collected. During the next part of analysis, data was sorted into categories using the research questions as a guide to develop initial codes and created new codes and themes as they emerged. The last step was axial coding also known as analytical coding, where we looked for relationships across codes and themes working back towards my theoretical framework (Merriam, 2014).

\section{Credibility}

Research that provides in-depth illustration using thick description and triangulation (the examination of how different sources of data on the same topic may complement each other to deepen understanding of a study topic) is considered credible (Bochner, 2000; Lapan et al., 2012; Ponterotto, 2006). Multivocality provides for a variety of opinions in qualitative research carefully attending to divergent viewpoints that may oppose the author or studied majority (Tracy, 2010). Multivocality requires the researcher to provide thick description of actors' performances interpretations they find meaningful (Lindlof \& Taylor, 2002). Qualitative researchers express the viewpoints that diverge within the majority or the author (Tracy, 2010).

The steps we took to ensure credibility provided rich and thick description. We were also able to utilize triangulation by examining the data collected as well as evidence provided by documents related to the topic. There were some divergent viewpoints in this study, especially within the legislator participants. Again, full, thick, and rich description of each viewpoint will assist the interpretation of meaning. The way my study is set up assured there would be divergence in perception and viewpoints.

\section{Ethical}

There are a variety of practices that attend to ethics in a qualitative study. Those include procedural, situational, relational, and exiting ethics (Tracy, 2010). The Institutional Review Board (IRB) encompasses procedural ethics. The IRB procedures include protection of the human subjects. We provided informed consent to all participants. We adhered to the Belmont Report recommendations of respect for persons, beneficence, and justice. We followed the university's IRB code of ethics. Every participant knew the purpose of the research. Moreover, the possible benefits and risks associated with the research were also made known. The rights of the individual to discontinue participation at any time; the protection; privacy and confidentiality; how the privacy and confidentiality are protected; and my contact information were supplied if any question(s) ever arise. The role of ethics is not to recommend a course of action but to reveal the possibilities and help assess the risks, if any (Holloway \& Todres, 2003). Participants were given the Informed Consent information explaining the objectives of the study as well as the protections provided to them as willing participants. All participants were given a copy of their signed forms and reminded that they may refuse any or all parts of the study at any time. We ensured confidentiality by omitting all names or identifying specifics in the final draft of the study.

\section{RESULTS}

The findings are organized as parts of a play. The introduction or exposition includes setting and characters. This is followed by the rising action consisting of the plot and themes. Next, comes the climax of the play. Then, there is the falling action, finishing with the resolution. 


\section{Exposition}

The setting is Kansas, culminating at the 2015 legislative session. The setting includes the Gannon decision, a court case pitting the State of Kansas vs. plaintiff students and school districts over equitable and adequate public school funding. This led to the replacement of the existing funding formula with block grants. The documents studied for this section include newspaper articles and court decisions regarding the Gannon lawsuit decisions. A legislator shared his take on causation of block grant reform,

I think one of the big factors was the governor had previously advocated some school finance changes and was unable to obtain legislative change in accordance with his desires. One way to get to that point was to completely eliminate the existing school finance formula so that it forced a conversation about school finance in a different way. The governor influenced this quite a bit.

This legislator believed the Governor took this drastic action in order to pursue his own agenda regarding school funding.

Another legislator remembered a slightly different narrative, one in which the governor did not cut education funds in exchange for getting legislative approval for the block grant. He recalled, "The governor proposed a \$60-70 million cut, but said he wouldn't do it to education if we approved the block grant...it was an arbitrary deal." The narrative was a little different, but the end goal was the same, which was the governor's desire to pursue his own agenda. A superintendent participant shared this theory,

There is dislike for the Supreme Court and the lower courts and all, there's opinion against school finance, which has ruled against the state multiple times. The governor and some of his legislator allies who wanted to remove the court justices, or defund them, appoint them differently, than the way it is currently. So, I think it was a lot of power struggle to get control of almost every branch of government. And so, I think this kind of put a hold on everything.

All the same, the block grants were to be based on the same formula under scrutiny, meaning even though the officials pushing the block grant by evidence of the old formula being outdated and hard to understand, the block grants were established using the same formula. It however, locked in at the 2014-2015 school year SBAPP rate for the two-year span, Shorman of the Topeka Capital-Journal reported in March 2015. One superintendent commented, " $50 \%$ of your budget is gonna impact education across the state and folks are voting on a bill that was gonna scrap a 20 -year-old finance formula." One legislator participant shared his interpretation of SB 7, "They're just trying to find, how do we get a fairly good educational process for the cheapest amount of money we can? Let's get away from giving a lot of money." In this legislator's view, the block grants were a way to ensure public schools were funded with the least amount they had to provide.

As explained in an article written by Llopis-Jensen in the Topeka Capital-Journal, in March of 2015, the block grants to temporarily fund schools were unveiled. This was a legislative response to the Governor's recommendation, again citing the reason to allow time for legislators to create a new finance formula for K-12 funding. No mention was made of utilizing educators or KSDE staff in creating a new school finance formula. The speed at which the block grant bill, also known as Senate Bill 7 (SB 7), was passed was attributed to a fast track tactic known as "gut and go," which is the practice of taking a previous bill and inserting another to rapidly advance the bill. This strategy also hindered the ability of senators to offer amendments to the bill.

An article in the Topeka Capital-Journal by Carpenter also in March of 2015 reviewed the bill's course. After only a week of deliberations in the Kansas House of Representatives and the Senate, Senate Bill 7 passed narrowly in both houses to be sent to Brownback to sign. Apparently, in the short amount of time, more than one version of the block grant was considered. A legislator explained the fact of the final version being the second block grant bill proposed,

We got it (SB 7) late in the calendar year. They did it, they voted it down and it was a massive effort to bring it back. In addition, it was critical, and this was going to be a two-year deal and we had to have that formula done.

The second plan was the version passed from the committees to the houses to examine. It was first introduced in the Senate and passed easily. The House amended the bill passed by the Senate. The first vote in the House of Representatives was short by two votes. It takes 63 votes to advance a bill and there were only 62 votes in favor of the bill. Republican leadership in the house utilized a procedural maneuver known as a call of the House to delay closure of voting, which provided time for absent members to get back to Topeka and vote. 
The result was a 64-57 final vote, enough to pass the bill in the House of Representatives. It was then sent to the Senate to have the amended form voted on, passing 25-14. Consequently, the legislation did not ensure or prevent future cuts from occurring during the block grants, which was an offered amendment in the House during debate. Although Senate Bill 7 was not the choice of educators, one superintendent offered a silver lining, "I would also say Gannon has created opportunities for discussions that maybe never ever would have taken place. Without Gannon, I don't think you have the people agreeing on the importance of an equitable funding system." With so much in motion, many stakeholders participated throughout the process, although only two main characters were of interest in this study.

\section{Characters}

Superintendents on status of relationships. The superintendents expressed a desire to have positive relationships with the legislators, but that did not always happen or was difficult at times. The superintendents who described having better working and personal relationships with their legislators had positive comments on opportunities for input into proposed legislation. A superintendent made communications with legislators a goal early, which was facilitated by the fact he had a prior relationship with one of them. He said, "I'd make regular contact with them. One is from my home town, and was a teacher in our district and was my boss for a while as a board member." Even legislators who did not want to directly engage with superintendents were still seen as open to compromise and discussion, if not debate.

Most superintendents believed a decent working relationship was important, even when the two parties did not agree with one another. This was illustrated by superintendents who claimed to have, as this one did, "Very strong [relationships] with the local legislators, even those who may not always agree, pretty strong relationships." Not all superintendents were able to connect with legislators, which caused a strain in the relationship or hurt the chance to develop a relationship. A few superintendents believed some legislators did not value public education, which made it a challenge to establish positive relationships with them.

Legislators on status of relationships. Legislators had a different perspective, but most agreed with the superintendents about the importance of keeping communication open and fostering personal relationships built on trust. If trust was not part of the equation, the relationship and opportunities to dialogue did not really occur and the relationship was strained or non-existent.

Some legislators described positive relationships with superintendents in their legislative district and some went to great lengths to reach out to their superintendents.

Other legislators described strained or non-existent relationships with superintendents. One described having a difficult time getting to know the person who was superintendent at the time of the block grant. He commented, "Our local superintendent at that time was new. I did not know him. He was only here for a short time. I never really got to know him."

\section{The Importance of Fostering Relationships}

Superintendents' perspectives. Superintendents in the study noted that relationships, while important, did not always happen naturally. They took energy and time, but paid off in the long term. Their peers saw some superintendents as having reservations or lacking the skills necessary for establishing relations with legislators. The effort is paramount, even if it was not fruitful at first or easily come by. A positive relationship rewards with connectivity, and when a superintendent is connected with a legislator, advocacy opportunities follow.

Advocacy was borne from fostering relationships and resources school superintendents spent ensuring they had an opportunity to be heard during policy creation. Relationships were viewed as the springboard to opportunity for superintendents to be heard as advocates for their schools. Again, if superintendents and legislators were to work together, relationships were the foundation of conversations and discussion surrounding a specific topic. If the relationship was strong, values and beliefs were respected, but did not need to be the driving force of debate. Relationships take time to develop and sustain, and superintendents understood it was not wise to establish those relationships while the legislative session was underway. Superintendents were quick to mention when real relationships were established. This was most effective during time away from the legislative session.

Legislators' perspectives. In the world of politics, legislators tread carefully when deciding with whom to develop relationships and trust. One legislator shared, "I think it's like anything else, you have to 
create trust, you have to create mutual respect for each other... If you ask a question I want to give an honest answer, I don't want a political answer. Legislators typically juggled more than one opinion from constituents and the superintendent and saw their role as a link between them. For example, this legislator said, "I am the liaison for the taxpayers to the school superintendent to let them know what the constituents are saying, and work with you."

For legislators, open and honest communication and the opportunity to be seen in a positive light were important for building and maintaining positive rapport with superintendents. A legislator commented on how he appreciated the open lines of communication established among his office and that of the board of education and district staff. Doing so allowed him to be seen in the community as an educational advocate through attendance at district events. Other legislators maintained regular communication with superintendents via phone calls and text messages.

\section{Rising Action}

The rising action takes place to develop the story line and draw the audience in, inferring what may occur during the climax. For this study, the rising action was in part the cause of the policy and the short 10-day time frame allowed for advocacy and input opportunities between superintendents and legislators. Senate Bill 7, the block grant funding for K-12 education in Kansas was fast tracked but according to the participants, the perceived catalysts of the bill put the motivations in motion well before the 2015 session.

\section{Theme}

The theme is the specific perspectives about the policy creation process during the SB 7 development of school superintendents and legislators. The lesson is understanding how superintendents perceive and are perceived in the process of advocating. The vehicle for studying the theme is what the participants believed to be the cause of the legislation. In this section, intertwined are superintendent and legislator comments.

Financial strain. The participants all shared their thoughts on the reasoning or causation behind the idea for the block grants. Superintendents and legislators alike found some common ground, which was the financial situation the state was facing since the 2012 legislation in which taxes were cut, resulting in a growing gap between projected and actual revenue. Another legislator divulged his agreement, acknowledging there were insufficient resources put toward funding anything, including education. He expressed, "Almost exclusively, scarcity of resources....and so it was a budget issue. It was a decision and a tactic driven by scarce resources."

Leadership influence. Pressure from leadership and the executive branch to balance the budget and find areas to increase efficiencies was also viewed as a contributing factor to the stopgap school funding policy. The block grants supplied the legislature with a viable option to have a concrete number to budget for in the coming two years, which was used as ammunition by legislative leaders.

Politics and ideology. Politics and ideology were another common theme for both legislators and superintendents when describing causes for SB 7. An ideologically conservative political climate was blamed for the eventual enactment of SB 7. To illustrate, one superintendent shared the thought of conservatism and the control of the Republican Party during the time, "In electing the governor and a legislature that would support him was to shrink government to the point, 'you could drown it in a bathtub.' That was a direct quote." Superintendents and some legislators tended to agree that the conservative political climate had the ultimate influence on the school funding policy of the time. The conservative political climate and the passage of SB 7 were seen by some as supporting an anti-public education stance.

Funding formula as political leverage. The Gannon court case was first filed in 2010 and argued not that the old funding formula was unconstitutional, but that underfunding it was. In general, superintendents felt the Gannon decision from the courts was a motivation for revisiting the funding formula.

A number of superintendents believed The Block grant legislation was a means to derail the Gannon lawsuit altogether.

Most legislators tended to disagree with the Supreme Court's ruling that the state was not adequately funding public schools. One legislator felt the Supreme Court had overstepped its power and bounds, noting there was "a level of resentment among some legislators with respect to actions of the Supreme Court in dealing with school finance issues."

Too much money spent on schools. A theme for legislators especially was the notion that schools already received too much money with little to no accountability or oversight. 
Many legislators posited the motivation for the Block grant was to save the state money. Another reason to cut expenditures might be, if schools, especially rural school districts lose weightings that counter-act or equate funding, it is possible they will be forced to consider joining neighboring districts.

Consolidation. Consolidation of school districts has been floating around the state for many years as a solution for strained state budgets. Participants speculated whether the state's fiscal crisis and debate over school finding would force some smaller districts to consolidate.

Flexibility and stability. Some legislators specifically saw the block grants and what was included in the bill as providing greater flexibility for districts to use their capital outlay budgets for other purposes to ease strain on general and supplemental general budgets. Superintendents advocate for students at the state level regarding policy initiatives. The advocacy in this case was a continued part of the rising action of the phenomenon.

\section{Advocacy of Superintendents}

Superintendents believed advocating in the most efficient manner ensured their efforts were focused. They intended to continue to develop relations with legislators to help them understand their roles, and not just influence policy.

Superintendents indicated getting others engaged in advocacy, such as community members and school board members was important. Relationships can lead to the opportunity to advocate as well as to offer written and formal testimony included in advocacy efforts.

When offering personal testimony to a committee, knowing the room and the audience were important when superintendents were preparing to testify before legislative committees. Sometimes the audience was hostile and superintendents had to be prepared to deal with negative feedback, inaccurate testimony, and false information. One superintendent shared an experience of having an adversarial audience and described how he handled the pressure, "It's knowing that there are people in the room who have absolutely polar opposite views. Sometimes you have to sit and listen to testimony being untruthful or promoting a point of view that's not accurate."

\section{Dialogue}

Lack of information and speed. Superintendents believed there was a lack of fundamental information about the bill shared amongst legislators themselves and other interested parties. Superintendents mentioned not knowing or hearing anything about the bill leading up to its introduction.

No dialogue. Another perspective of superintendents was the complete lack of transparency as evidenced by a lack of dialogue. That is, no dialogue was taking place between superintendents and legislators during the time.

Dialogue but little influence. Some superintendents expressed they were able to have conversations with legislators, but it was evident momentum was already underway, and they felt their voices were not heard. Superintendents felt the legislators were pushing their agenda and not listening to their education constituents.

Given the one-sided nature of the dialogue, it was not surprising that to some superintendents, the bill seemed to lack any educator's input in its design. It was suggested the block grant bill was not communicated well in advance, or even thought out entirely.

Legislators had a different perspective and referenced other conversations during the timeframe, not just those with superintendents.

\section{Legislator Perspectives}

Lobbyists. Lobbyists generally are employed by stakeholder groups to influence lawmakers for many different reasons. These advocates are paid to meet with legislators and communicate a side of an issue that best serves the purpose of their employer. Legislators were fully aware and the experienced ones knew how to navigate the various and sometimes competing messages. For example, one legislator represented most of the lawmakers of the study when he said, "I always joke with people, you get the best legislation money can buy. Because, if you've got enough money to hire a lobbyist, you can get what you need."

Superintendents. Legislators acknowledged school superintendents were engaged in the process at the time of the block grant development. Some superintendents took time to personally visit and have conversations with legislators. The legislator was impressed with the superintendents' ability to 
understand school funding structure and constitutionality, but also felt the conversation and advocacy were acts of futility. The superintendents were not a fan of the bill and communicated that to the legislator, even though the lawmaker did not see the chance to slow down the bill.

Some legislators experienced internal struggle over the decision during the critical days of the block grant development. There were opportunities for superintendents to offer input but there was no promise of a backup plan should the block grant fail to be passed. To illustrate, this legislator described his dilemma after talking with individuals and having phone conversations with superintendents,

I found out that not a single one of my districts supported it at that point. There were phone calls, emails and visits by superintendents during this time in the session. Before we voted, I was going back and forth, I'd get up in the middle of the night. If we blow this, we won't have anything. In the end, the big factor was they could not guarantee that they would fund it with no money. Why are they proposing something they can't pay for?

Legislators believed they were doing their best to listen to superintendents, who they felt might not understand all the political ramifications of not passing the block grant bill.

\section{Obtaining Input toward Policy}

Constituents. The legislators offered examples of times they took ideas to constituents at meetings or by polling them to determine a course of action on a proposed bill. They expressed their interest in reaching out to the people they represented by meeting with them and polling them. One legislator explained, "My goal is to be in contact with my constituents. I send out surveys. I want to know what they are saying." He believed the steps taken to make personal contact with stakeholders and explaining their purpose as a representative of the people has paid off. He described the outcome, "They will talk to you one-on-one. I work for my constituents, not for me. If $80 \%$ of my constituents answer a certain way, that's how I determine my vote."

Accordingly, specific education constituents were referenced such as school superintendents and board of education members whom the legislators represented as resources regarding school business and finance. A legislator indicated, "I think many of us go to superintendents in their area." Another legislator shared how he worked with local superintendents, "The real proof is visiting in person with superintendents, and then converse back and forth. 'Here's the real deal for us, here's the real deal for me.' Then, you decide after those conversations what direction you want to take." It was common for legislators to seek their superintendents' input in making educational policy determinations.

Legislative research. The Legislative Research Department, revisers (those who fact check and revise any proposed legislation) as well as KSDE staff including state board members and especially Deputy Commissioner Dale Dennis were listed as trusted sources regarding educational finance matters.

Legislators also leaned on KSDE board members and staff for input and information. As attested by one legislator, "The state board folks particularly Dale Dennis, is a great resource to get a more global grasp on the implications of school finance issues." Similarly, another legislator shared, "Dale Dennis from KSDE is a school finance guru. We use folks like that, what the research department and Dale do for us is take all the concepts and put it into figures and statutory language." -These were the input authorities frequently mentioned by legislators. This list is at odds with the input sources mentioned regarding the SB 7 Block Grant bill, when specifically asked regarding the SB 7 Bill, other influences were mentioned and there was no evidence from participants of KSDE or any of the staff being part of the conversation or influence.

\section{Perceived Influence on SB 7 Block Grants}

Special interest groups influence on legislative leadership. When asked who legislators turned to for expertise when constructing SB 7, superintendents shared their perceptions that the more powerful influences came from private conservative advocacy groups such as Kansas Policy Institute (KPI), Kansas Chamber, and the American Legislative Exchange Council (ALEC).

Superintendents tended to believe these conservative special interest groups were powerful influences on legislative leadership, some of whom were also members of these groups. For example, a superintendent made this observation about the influence of KPI and ALEC on the block grant idea, "Our legislators and leaders in each house are members of ALEC, so I think those are their first go-tos. During that time, it was purely KPI and ALEC, that was at least influencing." 
Several legislators shared their perspective on the private interest influence and even offered specific players in conservative lobbying circles. One legislator corroborated a similar sentiment of private lobbyist influence on leadership, "I think private interests controlled the leadership." Another legislator also asserted the motivation of these private interests was to reduce public education funding, "A resource would be the Kansas Policy Institute who have been on a mission to, they would say, to improve outcomes and eliminate inefficiency for our kids." But, the legislator went on to explain, "Their presence, their research, for those who are anti-government, and we still have a few of those." The same legislator continued sharing about KPI as an influence, "The KPI and other conservative outlets have plenty of ammunition to draw from.

Legislative leadership and committee assignments. Leadership and the structure of influential positions on the Education, Ways and Means, and Appropriations committees gave clear direction and were seen as the catalyst for the bill. One legislator confirmed the leverage of leadership to push SB 7 through the committee, "I really think the leadership wanted it." Therefore, legislative leaders were seen as manipulating the process to serve their own ends.

Study participants indicated the committee assignments were made to purposely load them with legislators who would support the bill and suppress opposition. A feeling existed that legislative leadership had undue influence in organizing the committees, but it was not in a legislator's best interest to go against the grain.

\section{Hidden Actions, Behind the Curtain}

These hidden actions were not lost on either group of participants. Legislators and superintendents alike mentioned the work that took place during this time away from public observation. A legislator shared the effort in securing votes to ensure a passing of the bill, "In trying to put votes together, this wasn't open, this was behind the scenes." Most legislators felt there were few influencers on the block grant and the committee structure led to little to no adversarial input.

In general, superintendents expected legislators to work beyond public consumption and they equated this practice to their own positions and work in local districts. At the local level, recommendations are often established behind closed doors depending on the immediacy and need of the decision. Oftentimes, the board of education questions the superintendent to ensure the best outcome is reached. Superintendents understood the legwork needing to be done out of the public eye, but having decisions made without the opportunity for input to be offered was different.

One superintendent shared this perspective,

The question is, has a decision already been made? I don't think your work as a superintendent, if you're going to recommend something to the board, that there wouldn't have been hours of planning in the community meetings or staff meetings the decision was going to impact. I don't think that when you presented it to board you would expect them to have zero questions. It's not whether or not the work is being done outside of committees, I think that is okay. The question is, who is involved and how transparent the system is, and then really, what is the opportunity for input?

Behind the curtain work was expected, even in superintendents' own work. Some participants shared their projections of how much behind the scenes work was conducted at the state level. When it came to policy creation, one superintendent estimated "that $70 \%$ is behind the scenes, $30 \%$ in front of the committees."

\section{Climax}

All of the participants shared distinct perceptions of the climax during the decision-making process of SB 7 Block Grants. The expediency and the path legislators took during the time shaped the views of superintendents and legislators alike. The legislators had a particular point of view showcased in the legislative action taken in the climactic events of the drama.

Legislative action is taken on every bill considered. A legislator must consider many influences. When asked how one determines legislative action, a legislator shared core beliefs as a driving force, regardless of any input offered by advocates surrounding the issue.

The process followed protocol, but was viewed as rushed and pushed through within a short time frame. A number of participants felt the outcome was pre-determined and lawmakers were merely going through the motions to comply with mandatory procedure. One superintendent shared, "There were hearings, the timeline leading up was very narrow, it was evident the decision had already been made." A 
legislator agreed, noting the fact that he had never experienced a bill proposal quite like it, "The votes were already there. There was no room for negotiation, no room for amendments. It was a done deal. It was really different."

\section{Falling Action}

When one side of the political spectrum is in power, it can have consequential impact on the governed. The perception of one party in particular having all the power led one superintendent to reflect on his days as an American History teacher and a book that was part of the curriculum that he believed summed up what was happening in Kansas. He observed, "If you take what's happened in Kansas, you could make the correlation in Animal Farm, really with one party ruling. This is what happens." In contrast, legislators concluded what happened was what was promised, that is, a chance to reset school funding. One legislator explained, "We did what we said we were going to do, I give them credit for that." Whether it was seen as a promise fulfilled or blatant abuse of power, the participants viewed the effects of the legislation in a widerange of ways.

If a bill is contentious, there is often outcry from constituents leading legislators to pay attention to the voices of the voters. In the case of SB 7, there was little community opposition, as many still believed that the tax plan would generate jobs and economic prosperity.

There was a sense among some participants that the outcome was exactly what was intended. Whether it was alternatives that were the ulterior motive or to improve efficiencies and create a new funding formula, unintended consequences forced legislators to address needs of school districts that faced hardships to a no-growth funding system.

\section{Resolution of the Drama}

Feelings after Bill Became Law. There was a sense of a political climate that converged to allow this particular hasty policy development that affected many parts of government. Included are thoughts of anger, bad business, willingness to derail the Gannon lawsuit, change the funding formula, and the antieducation sentiment many felt during the session. Several participants shared their commentary about the process, how it felt forced with no real opportunity for debate.

When an election cycle organizes an ideological strength that stretches over two branches of government meant to provide for checks and balance, the environment can breed actions of precedence. Conservative Republicans gathered a collective majority in the House, Senate, and the Governor's office in the 2010 election cycle. This paved the way for a shift in a fundamental belief system toward policy.

There were strong feelings following the passage of the law. Superintendents were unhappy and angry about how the bill would negatively affect their districts. Some felt it was a personal assault, as one superintendent said, "I knew what it was going to do to us. It looked like it was personal."

Participants mentioned bad business or bad policy led by misunderstanding of the equity and adequacy need in funding public education. A superintendent equated the decision to pass the block grants as a bad business decision because of equity. He said, "I was frustrated because I verbalized with legislators who were in on the planning. I knew it wasn't equitable, and I knew it was bad business.

Once the block grant bill passed into law, it repealed the old funding structure, paving way for a new formula. One superintendent felt that having a new formula provided motivation to legislators in making the decision, "I think it's because you had enough legislators that hated the finance formula and the governor even addressed the need to remove it in his State of the State speech."

\section{DISCUSSION and CONCLUSIONS}

\section{Setting}

\section{Conservative climate of policy creation influenced the outcome.}

The setting politically, has as much to do with a policy's chance in becoming law as does the issue it is addressing and how well it is crafted. The strength of the controlling party in a legislature contributes to a climate or feel of a session. In this case, an ultra-conservative branch of the Republican Party had control of the Executive and Legislative branches of Kansas government. They used their power and political influence to introduce a school finance bill that would undermine the Kansas Supreme Court and pushed forward a conservative political agenda for public education in Kansas. Most of the participants made it 
clear, the environment of the legislation of that time was different; the forceful manner in which the process was constructed and conducted had not been seen in recent years, or since.

\section{Symbolic Language: Promoting the Drama using Conservative Rhetoric}

It is evident that individuals' opinions are altered by consequences and political actions, supported by sources of authority (Edelman, 1988). As Koyama and Bartlett (2011) claim, policy-targeted problems are situated in vague claims. The stage for SB 7 was set as far back as the election results of 2012 in Kansas. The ever-shifting winds set in motion a conservative compilation of legislators that complimented the newly elected Governor Sam Brownback. The charge of the conservative movement of the time was to look for efficiencies and reduce expenses by shrinking government operations. While Governor Brownback publicly supported schools, his actions and support of policy during the time told a different story. With K12 funding being the largest expense to Kansas' general fund budget, it was apparent there would be a call to reform educational finance. The language used at this time was conservative rhetoric of efficiency and too much money being spent on education. The purpose of this language was to persuade the public that the judges were biased and overstepping their bounds. Brownback and his contingent used what is known as a bully pulpit to push their agenda, which included tactics such as the arm-twisting, systematic threats, and emotional manipulation.

Superintendents did what they could to influence the policy presented. Some had better access than others due to the relationships they had with legislators. As superintendents advocated for education and the importance of the investment and how it was good for every community, it was not persuasive enough to counter SB 7 because of the conservative political climate and the dominance in the legislature and governor's office.

\section{Casting the Play: The Drama between Superintendents and Legislators}

Power of authority in casting the play. These choice assignments included significant committee chairs and co-chairs who decided appropriations for the budget, including the education committees at the time. During the 2015 session, conservative Republicans held all of these pivotal positions and cleared the way for agenda priorities to be considered with not much resistance. It is the people in these roles who determine what bills were heard and which ones were not during the session. Therefore, when one party dominates and controls these positions, their agenda will be pushed and be considered strongly. Of course, there was discussion about what that agenda would entail behind closed doors, all of the participants understood the value of collaboration, even compromise having to take place out of public view. The crux in this particular case, was the decision already made behind closed doors, with little to no value given to collaboration and debate from others.

Relationships in politics. The legislative actors said they were influenced by their personal beliefs, respected community members, media, special interests, other legislators, the Legislative Research Department, and KSDE. Yet, the only voices that truly influenced these politicians were trusted people, established via personal relationships. Establishing and continuing personal relationships impacted decisions more than facts and knowledge of the subject. Sometimes that was their superintendents and other times it was other personal influences. However, sometimes the legislators went against what they believed or felt was right because the cost was too great, or the consequences were unknown. Some legislators admitted to voting for the bill because the political costs of opposing it were too high--they would have been removed from positions of influence on committees.

Superintendents understand the message they hear from some of these other sources might not align with the input they were given. As was evident in this case, the information shared by other superintendents did not always match their own.

Advocacy of superintendents. There has to be an investment in a legislator as a person first and foremost before authentic advocacy can occur. The message does not always have to come from the superintendent. School board members and parent advocacy groups are powerful motivators. Board members are officials elected by the same constituency, and parents are part of the communities served by the legislators as well. The more people advocating for a district and the students, the better. Again, relationships must be developed by these sources as well. While all of this is supported by the findings, it is apparent the actual relationships did not lead to influence this particular spectacle of policy development. 


\section{Illusion of Rationality}

It was clear in committee testimony and the language of the policy itself, private interests, such as Kansas Policy Institute, the Kansas Chamber of Commerce and other conservative groups had a heavy hand in the development and passage of SB 7. There were strategic testimonials in opposition of public education at the time. Proponents who were also architects of the bill, although lacking in number, had the lion's share of time offered to testify in front of the committees considering this legislation. In their testimony, they used data and language associated with the bill that was released only 24 hours earlier. In fact, many legislators on the committee had yet to receive a full version of the bill as testimony was being considered. All of the superintendents and many legislators saw SB 7 as a packaged deal. It was easy for the special interests to wrap their input in line with the bill, which offers the example as an illusion of rationality.

\section{Illusion of Participation}

In a politicized arena, where policy is crafted, the rationalization and democratic participation is an illusion created to merely offer a ritualistic procedure (M. L. Smith \& Miller-Kahn, 2004). During this spectacle, superintendents did not believe there was much opportunity for participation, whereas the legislators largely felt there were plenty of opportunities for participation from superintendents. This study provides an example where the formalized methods were carried out but far removed from where decisions are made. The SB 7 block grant was considered and predetermined by a select few legislators and special interest groups. The justification came by way of expressing that this bill would be as good as it gets for everyone. Should any further discussion or debate occur, it would be detrimental to schools and individual legislators. For this drama, relationships offered no positive or negative effect, but the process of the block grant policy did follow protocol, which is a fair description of illusion of participation.

\section{Distinguishing Actions: Values Backing Legislation}

Ready-made policy. In this political spectacle, a policy was created and supported behind closed doors. It is clear the policy of SB 7 block grants was destined to be passed in spite of relationships or superintendent efforts to advocate for public schools. The coalition of conservatives in favor of reducing expenses for the state anywhere and everywhere amidst the budget constraints was evident from the Governor's State of the State address to the repeal of the old formula and on to each house of the Kansas legislation dominated by conservative ideology. The block grant policy offset any further increases needed to utilize a growth funding formula. It is consistently referenced that proponents of the bill from external influencers had more than an outsider's knowledge of the components. In addition, the time given to prepare for testimony was only a 24-hour time period. All of this collectively offers the conclusion that the SB 7 bill already had enough support to pass, it was reflected as an effort in futility by many participants.

The action of passing this legislation into law provides evidence of value-based decision-making. The question remains, what value was the foundation? One can conclude, the need to do what is best for students and reformulate school funding to meet the needs of all students was not the foundation, however the line of thought to do whatever was necessary to cut funding from anywhere that is possible was the determining factor.

Furthermore, for this spectacle, influence primarily came from internal pressure or leverage. The influence appeared to have come from the power of suggestion provided by the Governor during his State of the State address that put legislators and anyone paying attention that he would use his clout to attempt to remove the old funding formula. Removal of the previous school funding formula opened the question of what to do next, and how to manage the constitutional responsibility posed by Article 6 of the Kansas Constitution. When an idea for school funding is suggested, especially from the executive branch of a state, people take notice. It was this point where superintendents and legislators diverged on the significance of advocacy efforts by school leaders in shaping the block grant bill.

The recommendations of superintendents and legislators revolved around building and maintaining relationships to have the opportunity for input on policy. In reflection, it may have assisted the study by incorporating agenda setting theory as an additional framework. 


\section{REFERENCES}

Angelucci, M., \& Di Maro, V. (2016). Programme evaluation and spillover effects. Journal of Development Effectiveness, 8(1), 22-43. doi:10.1080/19439342.2015.1033441

Baicker, K. (2005). The spillover effects of state spending. Journal of public economics, 89(2), 529-544. doi:10.1016/j.jpubeco.2003.11.003

Baker, B. D. (2005). History of school reform and litigation in Kansas., 27, 35.

Baker, B. D., \& Corcoran, S. P. (2012). The stealth inequalities of school funding: How state and local school finance systems perpetuate inequitable student spending. Retrieved from http://www.americanprogress.org:

Baker, B. D., Sciarra, D. G., \& Farrie, D. (2010). Is school funding fair? A national report card. Retrieved from

Bartlett, L., Frederick, M., Gulbrandsen, T., \& Murillo, E. (2002). The marketization of education: Public schools for private ends. Anthropology \& Education Quarterly, 33(1), 5-29. doi:10.1525/aeq.2002.33.1.5

Bennett, W. L., \& Iyengar, S. (2008). A new era of minimal effects? The changing foundations of political communication. Journal of communication, 58(4), 707-731. doi:10.1111/j.1460-2466.2008.00410.x

Bjork, L., \& Lindle, J. C. (2001). Superintendents and interest groups. Educational Policy, 15(1), 76. doi: $10.1177 / 0895904801015001005$

Bjork, L. G., \& Gurley, D. K. (2005). Superintendent as educational statesman and political strategist. The contemporary superintendent: Preparation, practice, and development.

Bochner, A. P. (2000). Criteria against ourselves. Qualitative Inquiry, 6(2), 266-272. doi: $10.1177 / 107780040000600209$

Bolman, L. G., \& Deal, T. E. (2003). Reframing organizations: Artistry, choice, and leadership. Hoboken, NJ: John Wiley \& Sons.

Bonewald, J. G. (2013). Perceptions of texas public school superintendents and legislators regarding strategies utilized by superintendents to influence the development of educational policies. (Doctor of Education), University of Texas at Austin, Austin, TX.

Brown, C. P. (2007). Keep it cheap, keep it local, and keep it coming: Standards-based accountability reform in Wisconsin. Educational Policy. doi:0.1177/0895904807307060

Campbell, J. L. (2002). Ideas, politics, and public policy. Annual review of sociology, 21-38. doi:10.1146/annurev.soc.28.110601.141111

Conley, D. T. (2003). Who governs our schools?: Changing roles and responsibilities. Williston, VT: Teachers College Press.

Cooper, B. S., Fusarelli, L. D., \& Randall, E. V. (2004). Better policies, better schools: Theories and applications. New York, NY: Pearson College Division.

Cortell, A. P., \& Peterson, S. (2001). Limiting the unintended consequences of institutional change. Comparative Political Studies, 34(7), 768-799. doi:10.1177/0010414001034007003

Creswell, J. W. (2012). Qualitative inquiry and research design: Choosing among five approaches. Thousand Oaks, CA: Sage

Edelman, M. (1985). The symbolic uses of politics. Chicago, IL: University of Illinois Press.

Edelman, M. (1988). Constructing the political spectacle. Chicago, IL: University of Chicago Press.

Fuller, H. L., Campbell, C., Celio, M. B., Harvey, J., Immerwahr, J., \& Winger, A. (2003). An impossible job. Retrieved from University of Washington, Seattle, WA:

Glass, T. E., Bjork, L., \& Brunner, C. C. (2001). The study of the American superintendency, 2000: A look at the superintendent of education in the new millennium: R\&L Education.

Gonzalez, G. M., \& Carney, C. L. (2014). Challenging the spectacle: A case study on education policy advocacy. International Journal of Leadership and Change, 2(1), 3.

Gordon, J., \& Patterson, J. A. (2013). Response to Tracy's under the "big tent" establishing universal criteria for evaluating qualitative research. Qualitative inquiry, 19(9), 689-695. doi: $10.1177 / 1077800413500934$

Gordon, J. A., \& Gordon, L. R. (2009). Of divine warning: Reading disaster in the modern age: Paradigm Pub.

Heise, M., \& Nechyba, T. (1999). School finance reform: A case for vouchers. . Retrieved from New York N. Y. Center for Civic Innovation: http://search.ebscohost.com/login.aspx?direct=true\&db=eric\&AN=ED468332\&site=ehost-live

Holloway, I., \& Todres, L. (2003). The status of method: flexibility, consistency and coherence. Qualitative research, 3(3), 345-357. doi:10.1177/1468794103033004

Hoyle, J. R., Bjork, L. G., Collier, V., \& Glass, T. (2004). The superintendent as CEO: Standards-based performance. Thousand Oaks, CA: Corwin Press.

Hughes, L. W., \& Hooper, D. W. (2000). Public relations for school leaders. Boston, MA: Allyn and Bacon. 
Johnson, S. M. (1996). Leading to change: the challenge of the new superintendency. . San Fransisco, CA: Jossey-Bass

Kansas Association of School Boards. (2014). Kansas Association of School Boards. Retrieved from http://www.kasb.org

Kansas Legislative Research Department. (2015). School finance and other education. Retrieved from http://www.kslegresearch.org/klrd.html

Kansas State Department of Education. (2014). Kansas State Department of Education. Retrieved from http://www.ksde.org

Kirst, \& Wirt. (2009). The political dynamics of American education. Richmond, CA: McCutchan.

Kirst, M. W., \& Wirt, F. M. (1989). Schools in conflict: The politics of education: McCutchan Publishing Corporation.

Koyama, J. P., \& Bartlett, L. (2011). Bilingual education policy as political spectacle: Educating Latino immigrant youth in New York City. International Journal of Bilingual Education and Bilingualism, 14(2), 171-185. doi:10.1037/e649012011-001

Lapan, S. D., Quartaroli, M. T., \& Riemer, F. J. (Eds.). (2012). Qualitative research: An introduction to methods and designs. San Francisco: Jossey-Bass.

Leachman, M., \& Mai, C. (2014). Most states funding schools less than before the recession. Retrieved from

Levin, B. (2000). Putting students at the centre in education reform. Journal of Educational Change, 1(2), $155-172$.

Lindlof, T., \& Taylor, B. (2002). Asking, listening, and telling. Thousand Oaks, CA: Sage Publications.

Lunenburg, F. C., \& Ornstein, A. C. (2004). Educational administration: Concepts and practices. California: Wadsworth Inc.

Maldonado, D. (2007). Working with the state legislaure: What superintendents are doing. (Doctorate of Education), University of Houston, Houston, TX.

Merriam, S. B. (2014). Qualitative research: A guide to design and implementation. Hoboken, NJ: John Wiley $\&$ Sons.

Oh, C. H., \& Rich, R. F. (1996). Explaining use of information in public policymaking. Knowledge and Policy, 9(1), 3-35. doi:10.1007/bf02832231

Ponterotto, J. (2006). Brief note on the origins, evolution, and meaning of the qualitative research concept thick description. The Qualitative Report, 11(3), 538-549.

Prestine, N. A. (2005). The eye of the beholder: superintendent perceptions of state systemic reform. Planning and Changing, 36(3-4), 193-216.

Reback, R., Rockoff, J., \& Schwartz, H. L. (2011). Under pressure: Job security, resource allocation, and productivity in schools under NCLB. Retrieved from

Rose, A. (2015). For the kids: A place for equity in kansas school finance litigation. Kansas Law Review, 63(5), 1205-1241.

Shorman, J. (2015). Brownback signs school block grant funding bill. Retrieved from http://cjonline.com website:

SSmith, M. L., \& Miller-Kahn, L. (2004). Political spectacle and the fate of American schools. New York, NY: RoutledgeFalmer.

Spring, J. (1998). Conflict of interests: The politics of American education (5th ed.). New York, NY: Queens College, City University of New York.

Tracy, S. J. (2010). Qualitative quality: Eight "big-tent" criteria for excellent qualitative research. Qualitative inquiry, 16(10), 837-851. doi:10.1177/1077800410383121

Wimpelberg, R. K. (1997). Superintending: the undeniable politics and indefinite effects of school district leadership. American Journal of Education, 105(3), 319-345. doi:10.1086/444159 